\title{
Profil Gambaran Endoskopi di Pusat Endoskopi KSM Ilmu Penyakit Dalam RSUP Prof. Dr. R. D. Kandou Periode Januari 2016 - Desember 2017
}

\author{
${ }^{1}$ Fadil Dewantara \\ ${ }^{2}$ Bradley J. Waleleng \\ ${ }^{2}$ Octavianus Umboh
}

\author{
${ }^{1}$ Program Studi Pendidikan Dokter Fakultas Kedokteran Universitas Sam Ratulangi Manado \\ ${ }^{2}$ Bagian Ilmu Penyakit Dalam Fakultas Kedokteran Universitas Sam Ratulangi Manado \\ Email: fadildewantara60@gmail.com
}

\begin{abstract}
Gastrointestinal endoscopy in the upper gastrointestinal tract is performed to obtain the condition of gastrointestinal mucosa. This study was aimed to obtain the profile of UGIB among endoscopy patients at the Gastrointestinal Endoscopy Center of Prof. Dr. R. D. Kandou Hospital Manado from January 2016 to December 2017. This was a descriptive retrospective study using medical records of patients who were registered at the Gastrointestinal Endoscopy Center from January 2016 to December 2017. The result shows that from 420 cases, there were 7 diagnoses after endoscopy, as follows: esophagitis, gastritis, erosive gastritis, gastric ulcer, gastric polyp, duodenitis, and hiatal hernia. The most common diagnosis of UGIB was gastritis in 155 cases (37\%), esophagitis in 124 cases (30\%), duodenitis in 40 cases (10\%), gastric polyp in 36 cases (9\%), hiatal hernia in 22 cases $(5 \%)$, erosive gastritis in 21 cases (4\%), gastric ulcer in 17 cases (4\%), and the other diagnoses (varices esophagus, esophagus ulcer, duodenum ulcer, achalasia) in 5 cases (1\%). UGIB occured more common in males with 227 cases (54\%) compared to female with 193 cases (46\%). The most frequent age group was 56-65 years old with 86 cases, and the most rare case was $>75$ years old. Conclusion: Upper gastrointestinal bleeding occured more common among males, aged 56-65 years. Gastritis was the most common diagnosis in endoscopy.
\end{abstract}

Keywords: endoscopy, upper gastrointestinal bleeding

\begin{abstract}
Abstrak: Pemeriksaan endoskopi pada saluran cerna bagian atas berfungsi untuk mengevaluasi keadaan mukosa saluran cerna atas dan sekitarnya. Penelitian ini bertujuan untuk mendapatkan profil gambaran endoskopi di Pusat Endoskopi KSM Ilmu Penyakit Dalam RSUP Prof. Dr. R. D. Kandou Manado periode Januari 2016 - Desember 2017. Jenis penelitian ialah deskriptif retroskpektif menggunakan data rekam medik pasien perdarahan SCBA yang melakukan pemeriksaan endoskopi periode Januari 2016 - Desember 2017. Hasil penelitian mendapatkan dari 420 kasus, ditemukan 7 diagnosis setelah tindakan endoskopi (EGD), yaitu esofagitis, gastritis, gastritis erosiva, gastric ulcer, polip gaster, duodenitis dan hernia hiatus. Diagnosis perdarahan SCBA terbanyak ialah gastritis 155 kasus (37\%), esofagitis yaitu 124 kasus (30\%), duodenitis 40 kasus (10\%), polip gaster 36 kasus (9\%), hiatus hernia 22 kasus (5\%), gastritis erosiva 21 kasus (4\%), gastric ulcer 17 kasus (4\%), dan kasus dengan dignosis lainnya (varices esophagus, esophagus ulcer, duodenum ulcer, achalasia) sebanyak 5 kasus (1\%). Perdarahan SCBA banyak terjadi pada pasien dengan jenis kelamin laki-laki berjumlah 227 pasien (54\%) dibandingkan dengan pasien perempuan berjumlah 193 pasien (46\%). Berdasarkan usia, terbanyak pada kelompok usia 56-65 tahun sebanyak 139 kasus dan terendah pada kelompok usia $>75$ tahun. Simpulan: Perdarahan SCBA lebih sering terjadi pada laki-laki, kelompok usia 56-65 tahun, dengan gastritis sebagai diagnosis terbanyak pada pasien perdarahan SCBA yang melakukan pemeriksaan endoskopi.

Kata kunci: endoskopi (EGD), perdarahan SCBA
\end{abstract}


Endoskopi gastrointestinal merupakan salah satu teknik dalam ilmu gastroenterologi-hepatologi untuk melihat secara langsung keadaan di dalam saluran cerna dengan menggunakan alat yang bernama endoskop. Endoskop digunakan sebagai pemeriksaan penunjang untuk menegakkan diagnosis, bahkan alat endoskop juga dipakai untuk tindakan terapeutik di saluran cerna. Seiring dengan waktu, hampir seluruh rumah sakit memiliki endoskopi sebagai suatu sarana pemeriksaan penunjang untuk membantu menegakkan diagnosis suatu penyakit dari gangguan saluran cerna. $^{1}$

Pemeriksaan endoskopi pada saluran cerna bagian atas (SCBA) disebut esofagogastroduodenoskopi (EGD) untuk mengevaluasi keadaan mukosa saluran cerna atas dan sekitarnya. Beberapa kasus indikasi peme-riksaan endoskopi yaitu perdarahan SCBA dengan ditemukannya gejala hematemesis dan melena. ${ }^{2}$

Perdarahan SCBA adalah kehilangan darah dalam lumen saluran cerna dimana saja, mulai dari esofagus sampai dengan duodenum di daerah ligamentum Treitz. ${ }^{3}$ Perdarahan SCBA termasuk salah satu kegawatdaruratan yang banyak ditemukan di rumah sakit seluruh dunia dan merupakan salah satu indikasi perawatan di rumah sakit dan banyak menimbulkan kematian bila tidak ditangani dengan baik. ${ }^{4}$

Penyebab perdarahan SCBA terbagi atas pecah varises esofagus dan non-varises seperti tukak peptik, gastritis erosiva, tumor, dan sebagainya. Penyebab perdarahan SCBA di Indonesia berbeda dengan penyebab di negara-negara Barat. Penyebab perdarahan SCBA terbanyak di Indonesia pada tahun 2008 yaitu pecahnya varises esofagus sedangkan di negara Barat penyebab perdarahan SCBA terbanyak (95\%) ialah non-varises yaitu $50-70 \%$ kasus karena perdarahan ulkus peptikum. ${ }^{5}$

Insiden perdarahan SCBA di dunia diperkirakan, yaitu 100-150 perawatan di rumah sakit per 100.000 populasi pertahun. Akibat perdarahan SCBA berkisar antara 7$14 \%$, sedangkan mortalitas karena perdarahan ulang mendekati $40 \%$ terutama pada pasien tua. ${ }^{4}$

Dari hasil penelitian yang dilakukan oleh Effendi ${ }^{6}$ di Bagian Instalasi Rekam Medis RSUP Prof. Dr. R. D. Kandou Manado pada periode Juni 2013-Juni 2015, diperoleh data sebanyak 139 kasus perdarahan SCBA, dengan akibat non-varises sebanyak $105(75,5 \%)$ kasus dan akibat varises sebanyak 34 (24,5\%) kasus. Kejadian tersering pada kelompok usia 56-65 tahun dan jenis kelamin laki-laki. ${ }^{6}$

Di Surabaya, dari 1.673 kasus perdarahan SCBA di Bagian Penyakit Dalam RSU Dr. Sutomo Surabaya pada tahun 2010 , penyebabnya ialah $76,9 \%$ pecahnya varises esofagus, $19 \%$ gastritis erosiva, $1,0 \%$ tukak peptik, 0,6\% kanker lambung, dan 2,6\% karena sebab-sebab lain. Penyebab perdarahan SCBA di RS Darmo Surabaya dilaporkan tukak peptik $51,2 \%$, gastritis erosiva $11,7 \%$, varises esofagus 10,9\%, keganasan $9,8 \%$, esofagitis $5,3 \%$, sindroma Mallory Weiss $1,4 \%$, dan tidak diketahui sebanyak 7\%. ${ }^{7}$

Berdasarkan data di Pusat Endoskopi Saluran Cerna (PESC) Rumah Sakit Cipto Mangunkusumo, terdapat peningkatan sebesar 26,2\% untuk pelayanan endoskopi dari tahun 2010 sebanyak 1.825 pasien sampai tahun 2011 sebanyak 2.303 pasien, baik yang menerima pelayanan untuk diagnosis maupun terapeutik di bagian Gastroenterologi. $^{7}$

Diagnosis yang lebih dini dan tepat pada pasien dengan perdarahan yang berat akan menurunkan angka mortalitas. Tujuan utama anamnesis, pemeriksaan fisis, dan pemeriksaan penunjang yang dilakukan ialah menentukan derajat perdarahan dan lokasi perdarahan. Dengan demikian, tujuan pengelolaan pasien dengan perdarahan saluran cerna, yaitu mempertahankan stabilitas hemodinamik, menghentikan perdarahan, dan mencegah perdarahan berulang, dapat segera dicapai.

Penelitian ini bertujuan untuk mendapatkan profil gambaran endoskopi di Pusat Endoskopi KSM Ilmu Penyakit Dalam RSUP Prof. Dr. R. D. Kandou periode Januari 2016 - Desember 2017. 


\section{METODE PENELITIAN}

Penelitian yang dilakukan bersifat deskriptif retrospektif dengan mengambil data sekunder di Instalasi Endoskopi KSM Ilmu Penyakit Dalam dan Instalasi Rekam Medik RSUP Prof. Dr. R. D. Kandou Manado.

Populasi penelitian yang diteliti ialah pasien endoskopi perdarahan SCBA di Instalasi Endoskopi Ilmu Penyakit Dalam RSUP Prof. Dr. R. D. Kandou periode Januari 2016 - Desember 2017. Sampel penelitian ialah data rekam medis pasien yang melakukan endoskopi di Instalasi Endoskopi KSM Ilmu Penyakit Dalam RSUP Prof. Dr. R. D. Kandou periode Januari 2016 - Januari 2018. Variabel penelitian antara lain jenis kelamin, kelompok umur, dan diagnosis endoskopi.

\section{HASIL PENELITIAN}

Pada hasil penelitian di Instalasi Endoskopi KSM Bagian Ilmu Penyakit Dalam RSUP Prof. Dr. R. D. Kandou Manado didapatkan sampel yang memenuhi kriteria inklusi sebanyak 420 pasien. Pasien endoskopi dengan perdarahan SCBA banyak terjadi pada jenis kelamin laki-laki berjumlah 227 pasien (54\%) dibandingkan jenis kelamin perempuan berjumlah 193 pasien (46\%).

Pada 420 kasus dengan perdarahan SCBA didapatkan bahwa yang tertinggi pada kelompok usia 56-65 tahun dan terendah pada kelompok usia $>75$ tahun (Tabel 1).

Tabel 1. Distribusi endoskopi berdasarkan kelompok usia

\begin{tabular}{ccc}
\hline $\begin{array}{c}\text { Kelompok usia } \\
\text { (tahun) }\end{array}$ & $\begin{array}{c}\text { Jumlah } \\
\text { kasus }\end{array}$ & Persentase \\
\hline $14-25$ & 23 & $5 \%$ \\
$26-35$ & 39 & $9 \%$ \\
$36-45$ & 66 & $16 \%$ \\
$46-55$ & 103 & $25 \%$ \\
$56-65$ & 139 & $33 \%$ \\
$66-75$ & 42 & $10 \%$ \\
$>75$ & 8 & $2 \%$ \\
\hline
\end{tabular}

Berdasarkan diagnosis endoskopi, didapatkan bahwa dari 420 kasus diagnosis terbanyak pada pasien endoskopi dengan perdarahan SCBA ialah esofagitis yaitu 124 kasus (30\%), gastritis 155 kasus (37\%), gastritis erosiva 21 kasus (4\%), tukak lambung 17 kasus (4\%), polip gaster 36 kasus (9\%), duodenitis 40 kasus (10\%), hiatus hernia 22 kasus (5\%), dan kasus dengan diagnosis lainnya (varises esophagus, tukak esofagus, tukak duodenum, dan achalasia) sebanyak 5 kasus (1\%) (Tabel 2).

Tabel 2. Distribusi berdasarkan diagnosis endoskopi.

\begin{tabular}{lcc}
\hline \multicolumn{1}{c}{ Diagnosis } & $\begin{array}{c}\text { Jumlah } \\
\text { kasus }\end{array}$ & Persentase \\
\hline Esofagitis & 124 & $30 \%$ \\
Gastritis & 155 & $37 \%$ \\
Gastritis erosiva & 21 & $4 \%$ \\
Tukak lambung & 17 & $4 \%$ \\
Polip gaster & 36 & $9 \%$ \\
Duodenitis & 40 & $10 \%$ \\
Hiatus hernia & 22 & $5 \%$ \\
Diagnosis lainnya & 5 & $1 \%$ \\
\hline
\end{tabular}

\section{BAHASAN}

Dari hasil penelitian yang bersifat deskriptif retrospektif di Instalasi Endoskopi KSM Bagian Ilmu Penyakit Dalam RSUP Prof. Dr. R. D. Kandou Manado periode Januari 2016 - Desember 2017 diperoleh data dari 420 pasien endoskopi dengan perdarahan SCBA. Diagnosis terbanyak pada pasien-pasien tersebut ialah esofagitis $(30 \%)$, gastritis $(37 \%)$, gastritis erosiva (4\%), tukak lambung (4\%), polip gaster $(9 \%)$, duodenitis $(10 \%)$, hiatus hernia (5\%), dan kasus dengan dignosis lainnya (varises esofagus, tukak esofagus, tukak duodenum, dan achalasia) (1\%).

Perdarahan SCBA dibedakan menjadi non-varises dan varises. Non-varises yaitu esofagitis, gastritis, tukak lambung, polip gaster, sedangkan varises yaitu varises esofagus. ${ }^{4}$ Pada penelitian ini didapatkan 7 diagnosis perdarahan SCBA dari hasil endoskopi (EGD), yang merupakan diagnosis pasti perdarahan SCBA.

Pada penelitian ini, didapatkan distribusi diagnosis endoskopi perdarahan SCBA non-varises lebih banyak dari pada varises. Hal ini sesuai dengan data yang 
dikumpulkan oleh American Society of Gastrointestinal Endoscopy, yaitu nonvarises lebih sering dibandingkan varises. ${ }^{1}$ Hasil yang sejalan juga diperoleh dari data Rumah Sakit Pemerintah di Makassar dan Rumah Sakit Swasta Darmo Surabaya yang melaporkan penyebab tersering perdarahan SCBA ialah non-varises. ${ }^{8}$ Dari data anamnesis dalam rekam medik pasien endoskopi di RSUP Prof. Dr. R. D. Kandou Manado didapatkan penyebab perdarahan SCBA terbanyak yaitu gastritis, gastritis erosiva maupun tukak lambung karena tingginya penggunaan obat anti inflamasi non steroid (OAINS) pada artritis gout, serta selanjutnya esofagitis akibat gastroesophangeal reflux disease.

Pada penelitian ini didapatkan kelompok jenis kelamin yang terbanyak menderita perdarahan SCBA ialah laki-laki (54\%) dibandingkan perempuan $(46 \%)$. Hasil ini selaras dengan penelitian Crooks et al. ${ }^{8}$ di Nottingham City Hospital yang mendapatkan penderita perdarahan SCBA terbanyak ialah pada jenis kelamin laki-laki. Hal ini juga sejalan dengan yang dilaporkan oleh Mccloskey et al. ${ }^{9}$ di Crosshouse Hospital UK yang mendapatkan penderita perdarahan SCBA terbanyak ialah pada jenis kelamin laki-laki. Umumnya laki-laki lebih sering terserang artritis gout dengan penggunaan OAINS. ${ }^{10}$

Dari hasil penelitian, menurut kelompok usia yang terbanyak menderita perdarahan SCBA ialah kelompok usia 56-65 tahun. Hal ini sesuai dengan penelitian Crooks et al. ${ }^{8}$ di Nottingham City Hospital yang mendapatkan bahwa yang terbanyak menderita perdarahan SCBA ialah kelompok usia 56-65 tahun.

\section{SIMPULAN}

Berdasarkan hasil penelitian terhadap pemeriksaan endoskopi pada pasien perdarahan SCBA di RSUP Prof. Dr. R. D. Kandou Manado periode Januari 2016 Desember 2017, dapat disimpulkan bahwa perdarahan SCBA lebih sering terjadi pada laki-laki, kelompok usia 56-65 tahun, dengan gastritis merupakan diagnosis terbanyak.

\section{DAFTAR PUSTAKA}

1. American Society for Gastrointestinal Endoscopy. GI endoscopes. 2011 [cited 2018 Nov 20]. Available from: http://www.asge.org/uploadedFiles/Pub lications_and_Products/Technology_R eviews/GI\%20Endoscopes(1).pdf

2. Kyoung OK. Normal upper GI findings and normal variants. In: Hoon JC, Suk KY, Myung GC, editors. Clinical Gastrointestinal Endoscopy. Berlin Heidelberg: Springer-Verlag, 2014.

3. Djojoningrat D. Patogenesis dan diagnosis perdarahan saluran cerna bagian atas. In: Simadibrata M, Abdullah M, Syam AF, editors, Proceeding Sym-posium Emergency in Gastroenterology. Jakarta: Pusat Informasi dan Penerbitan Departemen Ilmu Penyakit Dalam Fakultas Kedokteran Universitas Indonesia, 2006.

4. Simadibrata M. Penatalaksanaan perdarahan saluran cerna bagian atas non-varises peran penghambat pompa proton. In: Simadibrata M, Abdullah M, Syam AF, editors. Proceeding Symposium Emergency in Gastroenterology. Jakarta: Pusat Informasi dan Penerbitan Departemen Ilmu Penyakit Dalam Fakultas Kedokteran Univer-sitas Indonesia, 2006.

5. Abdurachman H. Pengelolaan dan pilihan terapi empirik pada perdarahan saluran cerna bagian atas non-varises. In: Simadibrata M, Syam A, editor. Update in Gastroenterology. Jakarta: Pusat Informasi dan Penerbitan. Departemen Ilmu Penyakit Dalam Fakultas Kedokteran Universitas Indonesia, 2005.

6. Effendi J. Profil pasien perdarahan SCBA (RSUP Prof. Dr. R. D. Kandou periode 2013-2015). eCl. 2015;4(1).

7. Adi P. Pengelolaan perdarahan saluran cerna bagian atas. In: Setiadi S, Alwi I, Sudoyo AW, Simadibrata M, Bambang, Setiyohadi, et al, editors. Buku Ajar Ilmu Penyakit Dalam Jilid II (6th ed). Jakarta: Interna-Publishing, 2014.

8. Crooks C, West J, Card R. Upper gastrointestinal haemorrhage and deprivation: a nationwide cohort study of health inequality in hospital admissions. Nottingham City: The University of Nottingham, 2011; p. 518-20.

9. McCloskey C, Craigen T, Angerson W, 
Shah A, Morran G. Mortality following blood transfusion for non-variceal upper gastrointestinal bleeding. Glasgow: University of Glasgow UK, 2011; p. 60-41.
10. Rosani S, Isbagio H. Arthtritis gout. In: Liwang F, Hanifati S, Pradipta E, editors. Kapita Selekta Jilid 2 (4th ed). Jakarta, 2014. 